\title{
Model of the Process of Preparing Annual Technical and Economic Plans in the Public Sector
}

\author{
Arkadiusz KUSTRA ${ }^{1)}$, Robert RANOSZ ${ }^{2)}$, Barbara KOWAL ${ }^{3)}$
}

\begin{abstract}
1) Ph.D., DSc, Eng.; AGH University of Science and Technology, Faculty of Mining and Geoengineering Cracow, Poland; email: bkowal@agh.edu.pl 2) Ph.D., DSc, Eng.; AGH University of Science and Technology, Faculty of Mining and Geoengineering Cracow, Poland; email: rranosz@agh.edu.pl 3) Ph.D., Eng.; AGH University of Science and Technology, Faculty of Mining and Geoengineering Cracow, Poland; email: bkowal@agh.edu.pl
\end{abstract}

http://doi.org/10.29227/IM-2020-01-76

Submission date: 14-11-2019 | Review date: 20-01-2020

\section{Abstract}

The article analyzes the process of preparing annual technical and economic plans in the public sector, on the example of the mining industry. Qualitative methods in the form of in-depth interviews (IDIs) were used in the analysis, consisting in conducting extensive interviews concerning the analyzed issues with representatives of coal companies. According to the study, the main aspect in creating a TEP for the analyzed mining companies is coal production. Taking into account the market environment and the reality of Polish coal companies, it was concluded that the starting point for the development of the TEP should not be the coal production or the pursuit of maximizing output volumes, but the sales market and demand for the raw material offered by individual companies. Three dimensions of TEP planning were also proposed.

Keywords: mining, public sector, Technical and Economic Plans (TEP), planning dimensions, value

\section{Introduction}

The article shows the process of preparing annual technical and economic plans in the public sector as exemplified by a listed company from the mining industry. A proposal for a model (procedure) for developing a Technical and Economic Plan (TEP) is presented. The plan is a key document in every business activity. A properly drawn up plan facilitates more accurate decision-making and helps achieve the set goals, which translates into an increase of the goodwill and a reduction of threats which could potentially arise in the future $[1,2$, $3,4,5]$. However, the development of a TEP in line with target requires coordination and cooperation with a number of departments preparing partial plans necessary for compiling an annual plan [6,7]. A well-thought-out and well-developed TEP planning procedure ensures the proper implementation of individual plans throughout the entire period, which eliminates the need to make further corrections in an ongoing TEP.

In its first part, the article presents the essence of the technical and economic plan in the operations of a business entity and the planning procedure for the preparation of annual TEPs in mining industry. The second part of the article is devoted to proposals for three dimensions of annual planning, ensuring balance in terms of objectives. The authors proposed three dimensions: the quantitative dimension of extraction and two financial dimensions: in terms of output and cash. The article ends with a summary which presents the conclusions from the presented procedure for the development of plans and proposed dimensions, as well as a list of references used in the study.

\section{The essence of the Technical and Economic Plan}

The Technical and Economic Plan results directly from the strategy of a given business entity, which is implemented at the highest level of organization. The strategy is usually formulated in a descriptive manner and primarily addresses general issues arising from the vision and mission of the entity, the direction which the company wants to pursue or the expectations of all stakeholder groups. It is referred to as "(...) an action plan defining the general scope of the organization's activities and ways of increasing the value of its individual parts (business units)" [8]. This action plan defines, on the one hand, the strategic objectives the entity wants to achieve, and on the other hand, the implementation of these objectives will contribute to increasing its value $[9,10]$.

Technical and economic plans translate the overall strategy into concrete, realistic and measurable objectives that the organization intends to pursue and achieve to a satisfactory level. The primary components of TEPs are:

- a production plan,

- an employment plan,

- an investment expenditure plan,

- a cost plan,

- a financial plan.

These elements should be closely interlinked and internally compatible. When creating a Technical and Economic Plan, it should be remembered that it is a document which presents certain assumptions on the basis of which the control of its execution will be carried out.

\section{Methodology and data used \\ The article presents the results of research comprising an analysis of the procedure for preparing annual technical and economic plans in the mining sector. The study consisted in re- viewing the largest possible number of documents, including: orders for the preparation of TEPs, procedures for drawing up annual and monthly plans of mining and other works and their thorough analysis. Due to the sensitivity of some of the data, the study based on qualitative methods in the form of IDI - in-depth interviews conducted with representatives of coal companies.}




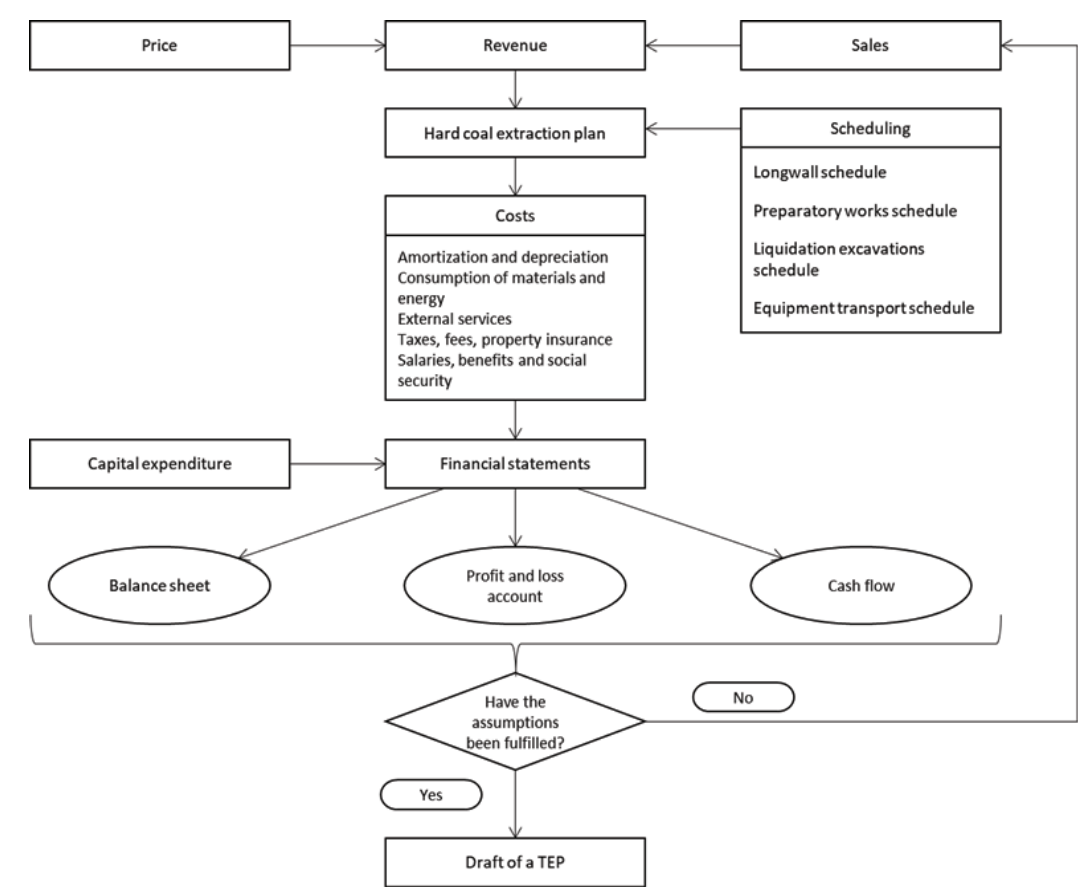

Fig. 1. Proposal for a general scheme of the process of preparing the Technical and Economic Plan in every mining company. Source: own elaboration Rys. 1. Propozycja ogólnego schematu przebiegu procesu przygotowania Planu Techniczno-Ekonomicznego w spółce górniczej, spółce giełdowej. Źródło: opracowanie własne

The cognitive goal of the research was to show how the process of preparing prepared annual Technical and Economic Plans is carried out in the public sector. Its practical goal was to propose three planning dimensions of this process.

\section{Model for the development of a technical and economic plan (TEP) in the public sector}

The analysis of available documents concerning the process of preparing Technical and Economic Plans in Polish mining companies has indicated that the starting point is the achievement of the assumed coal production plan, while the revenue part in the form of the Hard Coal Sales Plan in a breakdown into current and new customers and the Coal Transportation Costs and Revenues Plan as well as revenues from lease of fixed assets occupy one of the final positions.

In the opinion of the authors, the point of departure in the process of preparing the Technical and Economic Plan should be the determination of assumptions concerning the volume of coal sales and the price projections (market entry, market parameters). A general scheme of the process of preparing the Technical and Economic Plan in mining company is presented in Figure 1.

Taking into account the market situation of Polish coal companies, it is concluded that the forming of both of these parameters depends on them only to a small extent. This is the result of capital ties between the owner and individual companies. The indicated relations within the capital group determine the transfer prices and amounts of commercial coal, which are planned at the owner's level and at the same time accepted as determinants in the planning process within the companies. In consequence, the assumed level of transaction prices at the contracting stage and the quantity impact other financial figures in the extraction sector, i.e. investment expenditure and operating costs, and impose a schedule for the extraction plan. The difficulty in developing a Technical and Economic Plan therefore lies in such budgeting of expenses and planning of mining works that the objectives set and assumed by the Owner are achieved [11,2].

In the case of mining companies which are listed companies, the most important objectives to be achieved should be:

- to meet the owners' expectations in the form of an appropriate financial result, as its size is an advantage for shareholders in the form of dividends paid. The final financial result is mainly determined by the way the company generates its operating profit (EBIT, EBITDA). Therefore, given the limited possibilities of creating a revenue side, it should be reiterated that it is necessary to properly adjust costs to the market situation,

- ensure proper cash flow related to cash generation in individual operational areas, as well as in investment and financial areas, which, in the long run, will lead to an increase in the economic value of the company based on increasing benefits measured by cash flow,

- achieve satisfactory results in the area of resources by ensuring a so-called a "strong balance sheet" identified as the optimum level of assets financed from sustainable financing sources, at low cost of provisioning.

If the assumptions, understood as obtaining satisfactory financial results reflected in the elements of the financial statements, or achieving an adequate level of satisfaction, which can be determined, for example, by various types of Key Performance Indicators (KPI's), will be fulfilled - then the final model of the Technical and Economic Plan can be constructed and voted on by the Management Board.

If the KPIs do not reach a satisfactory level, the initial assumptions regarding the sales volume and price, as well as the relevant plans comprising the TEPs, such as: 
Tab. 1. A summary of basic quantitative parameters. Source: own elaboration

Tab. 1. Zestawienie podstawowych parametrów w wymiarze ilościowym. Źródło: opracowanie własne

\begin{tabular}{|c|c|c|c|c|}
\hline \multicolumn{2}{|c|}{ Current month } & \multirow{2}{*}{ Inventory } & \multicolumn{2}{|c|}{ YTD } \\
\hline Plan & Previous year & & Plan & Previous year \\
\hline & & $\begin{array}{l}\text { Total gross output } \\
\text { Total net output } \\
\text { Total advancement } \\
\text { Total yield }\end{array}$ & & \\
\hline
\end{tabular}

Tab. 2. A summary of basic result-oriented financial parameters. Source: own elaboration

Tab. 2. Zestawienie podstawowych parametrów finansowych w ujęciu wynikowym. Źródło: opracowanie własne

\begin{tabular}{l|c|c|c}
\multicolumn{2}{c|}{ Current month } & Inventory & \multicolumn{2}{|c}{ YTD } \\
Plan & Previous year & Plan & Previous year \\
\hline & Net output & \\
Price & \\
Revenue & \\
Operating expenses: & Salaries & \\
& Materials & \\
& Energy & \\
& External services and renovations & \\
& Amortization and depreciation & \\
& Other & \\
& EBIT & \\
& &
\end{tabular}

Tab. 3. A summary of basic flow-oriented financial parameters. Source: own elaboration

Tab. 3. Zestawienie podstawowych parametrów finansowych w ujęciu przepływowym. Żródło: opracowanie własne

\begin{tabular}{|c|c|c|c|c|}
\hline \multicolumn{2}{|c|}{ Current month } & \multirow{2}{*}{ Inventory } & \multicolumn{2}{|c|}{ YTD } \\
\hline Plan & Previous year & & Plan & Previous year \\
\hline & & \begin{aligned} & \multicolumn{1}{c}{ EBIT } \\
$= &$ Tax \\
$= &$ NOPAT \\
+ & Amortization and depreciation \\
+ & - CAPEX \\
+ & - Net working capital requirement \\
$= &$ Cash Flow \end{aligned} & & \\
\hline
\end{tabular}

- scheduling mining works,

- generally understood operating expenses,

- $\quad$ capital expenditure, should be verified.

The elements listed above are not easy to change altogether, although they can be designed to a limited extent. Considering the high fixed costs resulting from the high involvement of fixed assets and high operational risk, it is necessary to ensure proper mining conditions and optimize both production and the assets owned for the owner's needs.

The presented scheme of the process of preparing the Technical and Economic Plan does not assume any price renegotiations and reflects the conditions of annual contracting, when the specific transaction price is established between the owner and the company. Nonetheless, this cannot be ruled out. It should be noted that this would be the last resort.

Implemented, the Technical and Economic Plan should not be subject to constant changes but should provide a basis for determining the deviations between the implementation and its objectives. Moreover, the resulting deviation in the decision-making process should, in turn, determine the process of correcting future budgets, ensuring the implementation of the annual objectives adopted in the TEP. If the adopted annual targets are not realistic, a future budgetary adjustment may not reflect market conditions and thus an adjustment of the TEP must be performed, but it is suggested that it should only take place once a year, e.g. after six months. As a result, the TEP and annual targets will be changed, which will certainly affect the company's stock market image, but at the same time will provide a settlement and analysis of deviations from the real-life operating processes.

\section{Annual planning dimensions}

According to Figure 1, in the course of the TEP development process, two planes appear, namely: the quantitative one - from which the planning process begins, and the financial one - which answers the question whether satisfactory effects have been achieved in the sense of satisfaction of the owners with the effects (adequate financial result, appropriate cash flow and achievement of satisfactory effects in the area of resources). Therefore, three planning dimensions are proposed and the objectives resulting from the creation of the Technical and Economic Plan are presented in a balanced way. These dimensions include:

- a quantitative dimension - extraction, progress,

- a financial dimension - focusing on the results,

- a financial dimension - focusing on the cash.

Each of the proposed dimensions is relevant and should not be considered separately, since all these areas are interconnected, as the company must implement the quantitative plan while maintaining appropriate financial parameters. These dimensions determine the basic parameters for a particular plane and its approach. The form of their presentation is arbitrary, however, its legibility and clarity should be maintained.

The first of these dimensions is the quantitative dimension. It should include a summary of the basic quantitative parameters which should be planned. Among them are: 
- $\quad$ total gross output $[\mathrm{Mg}]$,

- total net output $[\mathrm{Mg}]$,

- total advancement [m],

- $\quad$ total yield [\%].

Bearing in mind the advisability of creating such lists, such plans should be prepared for the "lowest" organizational levels in the company. According to the authors' knowledge, within the organizational structure of mining companies, at least three levels can be distinguished, starting from the highest organizational level: the company as a whole, individual mining fields and longwalls assigned to individual fields.

A table layout is proposed below, presenting a summary of plans for each month relative to the performance from the previous year (Table 1). The presented layout should apply to all organizational levels.

Caution must be exercised when planning quantitative parameters. Plans should not be overly optimistic. It would also be advisable for each of the figures presented to be justified by appropriate documentation.

Finance is the second of the planned dimensions. It is considered to be equally important to quantitative planning. For this area, planning should be carried out in two approaches:

- focusing on the result,

- focusing on the cash.

Due to the nature of the Technical and Economic Plan, the authors decided to limit the full profit and loss account to the operational level. The result-oriented financial dimension should include a summary of the basic financial parameters which should be planned. Among them are:

- net output,

- price,

- sales revenue,

- operating expenses:

o salaries,

o materials,

o energy,

o external services and repairs,

o amortization and depreciation,

o other,

- EBIT

As with the quantitative dimension, such plans should be prepared for the "lowest" organizational levels within the company. Similarly, three planes can also be distinguished here: the company as a whole, individual mining fields and walls assigned to individual fields

A model tabular layout showing a summary of plans in financial terms for each month in relation to the performance for the previous year is presented in Table 2.

The third element is the financial dimension focusing on cash. As in previous cases, for the cash flow, the authors propose a very simplified version of this document for readability reasons. This dimension should include a summary of the basic financial parameters which should be planned. Among them are:

- $\quad$ EBIT,

- tax,

- NOPAT,

- amortization and depreciation,

- CAPEX,

- net working capital requirement,

- cash flow.

As in the case of the quantitative and financial dimension focusing on the results, such plans should be prepared for the "lowest" organizational levels in the company. Similarly, three planes can also be distinguished here.

A model tabular layout of the basic parameters for the financial dimension in terms of cash flow is presented in Table 3 .

\section{Summary}

The article points out that the problem of creating a technical and economic plan is an important element of the functioning of every company. The process of developing TEPs is extremely important from the point of view of proper designation of objectives, taking into account external market conditions and their effective implementation. Therefore, mining companies should make every effort to ensure that the process of its preparation takes place and runs as correctly as possible. The primary advantages of proper preparation of a TEP include: streamlining of the process of its implementation, flexibility in setting limit values/divisions, provision of information necessary for proper decision-making, improved and clearer control of all activities in the company, improvement of mutual communication and coordination. The article does not address the issue of employee motivation, although it is an important component in improving the effectiveness of work

The idea of proposed model presented in this article is that the company should to adjusts its production capacity to the volume of demand, while maintaining certain parameters such as price and KPIs. Achieving the KPI's, especially those which are considered important for the owners, will set the company on a proper path to achieve its objectives, and will eliminate the need to adjust the TEP, as well as increase the value of the entire enterprise.

The presented dimensions of the planning process - quantitative and financial dimensions focusing on results and cash - contribute to a balanced approach to the process. All the proposed areas are equally important and necessary to improve and properly implement the preparation of TEPs. The basic parameters of the dimensions should be based on a simple and readable value which should serve as the objective.

The authors are aware that the article is not exhaustive. It is a proposal which has been dictated by industry observations and interviews.

This paper was supported by the AGH University of Science and Technology [No. 16.16.100.215]. 


\section{Literatura - References}

1. Kowal, B., Ranosz, R., Karkula, M., Kowal, D. Process Management in Hard Coal Mining Companies, Journal of the Polish Mineral Engineering Society 2018, iss. 2 (42), 111-116.

2. Bąk, P. Planning in mining enterprise management. Scientific Books of the Szczecin University 2014, 804, 531-541.

3. Sierpińska, M.; Jachna, T. Methods of making financial decisions - analysis of examples and cases, Scientific Publisher PWN, Warszawa, 2007.

4. Groeneveld, B.; Topal, E.; Leenders, B. Robust, flexible and operational mine design strategies. Min. Technol. 2012, 121, pp. 20-28, 10.1179/1743286311Y.0000000018.

5. Bluszcz, A.; Kijewska, A.; Sojda, A. Economic Value Added in metallurgy and mining sector in Poland. Metalurgija 2015, 54, iss. 2, 437-440.

6. Kazakidis, V.; Scoble M. Planning for flexibility in underground mine production systems. Min. Eng. 2003, 55, 3338 .

7. Dowd, P.; Xu, C.; Coward, S.J. Strategic mine planning and design: some challenges and strategies for addressing them. Min. Technol. 2016, 1-13, 10.1179/1743286315Y.0000000032.

8. Johnson, G.; Scholes, K.; Whittington, R. Basics of strategy, Polish Economic Publisher, Warszawa, 2010.

9. Fernanda Del Castillo, M.; Dimitrakopoulos, R. Dynamically optimizing the strategic plan of mining complexes under supply uncertainty. Resources Policy 2019, 60, 83-93.

10. Bluszcz, A.; Kijewska, A. Factors creating economic value added of mining company. Archives of mining sciences 2016, 61, iss. 1, 109-123.

11. Montiel, L.; Dimitrakopoulos, R. A heuristic approach for the stochastic optimization of mine production schedules, J. Heuristics 2017, 23, 397-415, 10.1007/s10732-017-9349-6.

Model procesu przygotowywania rocznych planów techniczno-ekonomicznych
w sektorze publicznym
W artykule poddano analizie proces przygotowywania rocznych planów techniczno-ekonomicznych w sektorze publicznym, na przy-
kładzie branży górniczej. W analizie wykorzystano metody jakościowe w postaci IDI - in-depth interviews, polegajaca na prze-
prowadzeniu pogłębionych wywiadów z przedstawicielami spótek weglowych dotyczacej prezentowanej problematyki. Jak wynika
zprzeprowadzonych badań, głównym aspektem w tworzeniu planu PTE dla analizowanych spółek górniczych jest wielkość produkcji.
Biorąc pod uwage otoczenie rynkowe oraz realia polskich spółek weglowych stwierdzono, iż punktem wyjścia przy opracowywaniu
planu PTE nie powinna być wielkość produkcji i maksymalne dążenie do zwiększania wielkości wydobycia, a rynek zbytu i wielkość
zapotrzebowania na oferowane przez poszczególne spółki surowiec. Zaproponowano również trzy wymiary planowania PTE.

Słowa kluczowe: górnictwo węla kamiennego, sektor publiczny, plany techniczno-ekonomiczne, wymiary planowania, wartość 
